\title{
Enzymatic hydrolysis of sorghum straw using native cellulase produced by $T$. reesei NCIM 992 under solid state fermentation using rice straw
}

\author{
A. Vimala Rodhe $\cdot$ L. Sateesh $\cdot$ J. Sridevi $\cdot$ \\ B. Venkateswarlu $\cdot$ L. Venkateswar Rao
}

Received: 30 April 2011 / Accepted: 6 September 2011/Published online: 20 September 2011

(C) The Author(s) 2011. This article is published with open access at Springerlink.com

\begin{abstract}
Cellulose is a major constituent of renewable lignocellulosic waste available in large quantities and is considered the most important reservoir of carbon for the production of glucose, for alternative fuel and as a chemical feedstock. Over the past decade, the emphasis has been on the enzymatic hydrolysis of cellulose to glucose and the efficiency of which depends on source of cellulosic substrate, its composition, structure, pretreatment process, and reactor design. In the present study, efforts were made to produce cellulase enzyme using rice straw. The produced enzyme was used for the hydrolysis of selected lignocellulosic substrate, i.e., sorghum straw. When rice straw was used as a substrate for cellulase production under solid state fermentation, the highest enzyme activity obtained was 30.7 FPU/gds, using T. reesei NCIM 992. 25 FPU/g of cellulase was added to differently treated (native, alkali treated, alkali treated followed by $3 \%$ acid treated and alkali treated followed by 3 and 5\% acid treated) sorghum straw and hydrolysis was carried out at $50{ }^{\circ} \mathrm{C}$ for $60 \mathrm{~h}$. $42.5 \%$ hydrolysis was obtained after $36 \mathrm{~h}$ of incubation. Optimization of enzyme loading, substrate concentration, temperature, time and buffer yielded a maximum of $546.00 \pm 0.55 \mathrm{mg} / \mathrm{g}$ sugars $(54.60 \pm 0.44 \mathrm{~g} / \mathrm{l})$ with an improved hydrolysis efficiency of $70 \pm 0.45 \%$. The enzymatic hydrolyzate can be used for fermentation of ethanol by yeasts.
\end{abstract}

A. Vimala Rodhe $\cdot$ L. Sateesh · J. Sridevi .

L. Venkateswar Rao $(\square)$

Department of Microbiology, UCS, Osmania University,

Hyderabad, India

e-mail: vrlinga@gmail.com

B. Venkateswarlu

CRIDA, Hyderabad, India
Keywords Cellulase - Enzyme hydrolysis ·

Rice straw $\cdot$ Sorghum straw $\cdot$ T. reesei NCIM 992
Abbreviations
Fpase Filter paperase
PDA Potato dextrose agar
gds Gram dry substrate
FPU Filter paper units

\section{Introduction}

The increasing concerns about the depletion, shortage of fossil fuels and air pollution caused by incomplete combustion of fossil fuels have led to specific focus on the production of cellulosic bioethanol from renewable lignocellulosic substrates such as wheat straw, rice straw, sugarcane bagasse, etc. (Sun and Cheng 2002).

Lignocellulose is considered as an attractive feedstock for the production of fuel ethanol, because of its availability in large quantities at low cost (Cheng et al. 2008) and they are composed of lignin and sugars polymerized to cellulose and hemicellulose that can be liberated by hydrolysis (acid/enzyme) and subsequently fermented to ethanol by microorganisms (Mussatto and Roberto 2004).

Rice straw is one of the most abundant lignocellulosic waste by-products worldwide and has an estimation of global production of 600-900 million tons per year (Karimi et al. 2006). Andhra Pradesh is an agriculturalbased state of India. The major crops grown are rice, groundnut, maize, sugarcane and sorghum (Reddy and Sanjana 2003). 
The annual production of sorghum straw in Andhra Pradesh is 764.4 tones. A total ethanol production of 0.335 GL could be achieved on the fullest utilization of the crop residue (Kim and Dale 2005). Sorghum is drought resistant and need only limited water conditions to grow. Due to its high biomass and carbohydrate contents (Mehmood et al. 2009) it is most promising for ethanol production. In our analysis sorghum straw was found to contain significant amounts of holocellulose (63\%) making this substrate suitable for bioethanol production.

Regardless of the type of cellulosic feedstock, the cost and hydrolytic efficiency of enzymes are major factors that restrict the commercialization of the biomass bioconversion processes (Galbe and Zacchi 2002). Development of an economical process for cellulase production is hindered because of the high costs of substrate (pure cellulose).

Cellulase enzyme is used to break up cellulose into glucose or other oligosaccharide compounds (Acharya et al. 2008). The cellulase system in fungi comprises three hydrolytic enzymes acting synergistically (Lynd et al. 2002), endo-1,4- $\beta$-D-glucanase [carboxymethyl cellulase (EC.3.2.1.4)], which cleaves $\beta$-linkage randomly in the amorphous parts of cellulose; exo-1,4- $\beta$-D-glucanase [cellobiohydrolase (EC.3.2.1.91)], which hydrolyzes cellobiose from either non-reducing or reducing end, generally from the crystalline parts of cellulose; $\beta$-glucosidase [cellobiase (EC.3.2.1.21)], releases glucose from cellobiose and short chain cellooligosaccharides (Wilson 2009).

Commercial cellulase enzymes could be used to convert lignocellulose into reducing sugars (Wen et al. 2005). The cost of commercial cellulase enzyme is very high; hence, this process is non-economical (Von Sivers and Zacchi 1995). The enzyme production cost accounts for approximately $40 \%$ (Spano 1978) of the total cost of bioethanol production and connected to the productivity of microbial strain and the final activity of enzyme in the fermentation broth (Himmel et al. 1999). The cost of raw material is the limiting factor in developing an economic process for cellulase production (Reczey et al. 1996). The economy of cellulase production could be improved by the use of cheap cellulosic substrates for enzyme production (Lynd et al. 2002)

Enzyme complexes for the degradation of lignocelluloses have been produced by solid state fermentation (SSF) on various agricultural residues such as rice straw, wheat bran, corn stover, sugarcane bagasse, pomace, corncobs, etc. (Soccol and Vandenberghe 2003), using host-specific fungi for best results (Nigam and Singh 1996).

SSF is successfully used over submerged fermentation for large scale production of fungal metabolites as it resembles the natural habitat for filamentous fungi to grow and produce the fermented products (Pandey 2003). SSF, a highly attractive and alternative process needs to be exploited for generation of cellulolytic enzymes with the use of cheaply available lignocellulosic residues and low input of process engineering. SSF is preferred due to low capital investment and lower operating cost (Rodriguez Couto and Sanroman 2005), higher product yield, better product quality, cheaper product recovery and cheaper technology (Oguntimein et al. 1992).

Among several microorganisms evaluated so far, organisms belonging to the genera of Trichoderma and Aspergillus are known to be potential cellulase producers (Kumar et al. 2008). Currently, most commercial cellulases, including $\beta$-glucosidases, are produced by Trichoderma species and Aspergillus species (Cherry and Fidantsef 2003).

Enzymatic hydrolysis of cellulose is carried out by highly specific cellulase enzymes. A mixture of endoglucanases, exoglucanases, $\beta$-glucosidases and cellobiohydrolases is commonly used (Mansfield et al. 1999).

Making cellulose accessible to the enzymes is an essential factor to increase the rate of hydrolysis (Philippids and Smith 1995). Therefore, chemical pretreatment, usually alkaline pretreatment, is necessary before enzymatic hydrolysis. Chemical pretreatment not only removes lignin but also acts as a swelling agent, which enhances surface area of the substrate accessible for enzymatic action (Kim et al. 2008).

The enzyme hydrolysis is usually conducted at mild conditions ( $\mathrm{pH} 4.8$ and temperature $45-50{ }^{\circ} \mathrm{C}$ ) and does not have a corrosion problem (Duff and Murray 1996). Moreover, it is possible to obtain hydrolysis of close to $100 \%$ by enzymatic hydrolysis, whereas it is difficult to achieve such high yield with acid hydrolysis. Several inhibitory compounds are formed during acid hydrolysis and this problem is not so severe for enzymatic hydrolysis (Lee et al. 1999).

The factors that affect the enzymatic hydrolysis of cellulose include substrates, cellulase activity and reaction conditions (temperature, $\mathrm{pH}$, etc.). To improve the yield and rate of the enzymatic hydrolysis, optimizing the hydrolysis process and enhancing cellulase activity need to be focused (Cantwell et al. 1988).

During the enzymatic hydrolysis, cellulose is depolymerized by the cellulases to monomeric reducing sugars that can be fermented by yeasts or bacteria to ethanol.

In the present study, cellulases were produced on the alkali pretreated rice straw with $T$. reesei NCIM 992, and subsequent hydrolysis of the sorghum straw, a lignocellulosic substrate with the cellulase produced was investigated. The hydrolytic potential, in terms of total reducing sugar yields obtained with the produced cellulase, was evaluated and the sugars obtained can be further employed in bioethanol production. 


\section{Materials and methods}

\section{Microorganism}

T. reesei NCIM 992 was procured from National Collection of Industrial Microorganism (NCIM), National Chemical Laboratory, Pune, India and maintained on potato dextrose agar (PDA) agar at $4{ }^{\circ} \mathrm{C}$ for subsequent use as inoculum.

Fungus cultivation for spore production and inoculum preparation

The fungal culture was grown on PDA slants and the spores were harvested aseptically from 5-day-old PDA slants. Sterile distilled water containing $0.1 \%$ (w/v) Tween-80 (Smits et al. 1996) was added to each fungal slant and vortexed. Spore count was measured with haemocytometer and adjusted to $2 \times 10^{6}$ spores/ml by adjustment of optical density.

\section{Substrate preparation and sterilization}

Rice straw was obtained from the outskirts of Hyderabad, pulverized to obtain a particle size of 2-3 mm. The substrate was washed with tap water and dried in oven at $50{ }^{\circ} \mathrm{C}$. The dried and powdered rice straw was soaked in $1 \% \mathrm{KOH}$ for $4 \mathrm{~h}$ at room temperature. After treatment, excess alkali was decanted and the substrate was washed with distilled water till it reached neutral $\mathrm{pH}$ and dried overnight at $50{ }^{\circ} \mathrm{C}$.

\section{Medium composition}

The growth medium used in SSF process consisted of mineral salts and trace elements (g/l): urea, $0.3 ; \mathrm{NH}_{4} \mathrm{SO}_{4}$, 1.4; $\mathrm{CaCl}_{2} \cdot 2 \mathrm{H}_{2} \mathrm{O}, 0.4 ; \mathrm{KH}_{2} \mathrm{PO}_{4}, 2 ; \mathrm{MgSO}_{4} \cdot 7 \mathrm{H}_{2} \mathrm{O}, 0.3$; peptone, 1; Tween-80, 0.2; $\mathrm{FeSO}_{4} \cdot 7 \mathrm{H}_{2} \mathrm{O}, 0.005$; $\mathrm{MnSO}_{4} \cdot 7 \mathrm{H}_{2} \mathrm{O}, 0.016 ; \mathrm{ZnSO}_{4} \cdot 7 \mathrm{H}_{2} \mathrm{O}, 0.014 ; \mathrm{CoCl}_{2} \cdot 6 \mathrm{H}_{2} \mathrm{O}$, 0.2; PSAC, 10; agar, 17.5; Triton-X 100, $1 \mathrm{ml}$; pH-5.3 (Mandels and Andreotti 1978). 1\% lactose was used as an inducer ( $\mathrm{Xu}$ et al. 2008). The medium was used to adjust initial moisture content $(80 \%)$ and autoclaved at $121{ }^{\circ} \mathrm{C}$ for $10 \mathrm{~min}$.

\section{Enzyme production under SSF}

Different lignocellulosic substrates such as rice straw, sorghum straw, wheat straw, saccharum, corn cobs, etc., were initially screened for their suitability for cellulase enzyme production by $T$. reesei NCIM 992, under solid substrate fermentation. Rice straw was found to be a suitable solid substrate for higher yields of cellulase and hence in the present study, fermentation was carried out under SSF using rice straw as substrate. Solid substrate $(10 \mathrm{~g})$ was mixed with nutrient supplement $(\mathrm{pH} 4.5)$ in $250 \mathrm{ml}$ flask to obtain a $1-2 \mathrm{~cm}$ layer of mixture without free liquid. The flasks were sterilized by autoclaving, cooled, shaken thoroughly to break the mass.

Inoculation process

Spore suspension $\left(2 \times 10^{6} \mathrm{ml}^{-1}\right)$ was transferred at $2 \%(\mathrm{v} / \mathrm{w})$ per flask. The contents in the flasks were mixed thoroughly to ensure uniform distribution of the inoculum.

Growth and enzyme production

The growth of $T$. reesei NCIM 992 and enzyme production was carried out at $28{ }^{\circ} \mathrm{C}$ under static conditions for 6 days.

Sampling process

The substrate was mixed for 5 min prior to sampling process. Sampling was done for every $24 \mathrm{~h}$. The sample was used to determine the activity of the enzyme produced.

\section{Enzyme extraction}

The enzyme was extracted by a simple contact method (Krishna and Chandrasekaran 1996). The fermented samples were shaken $(150 \mathrm{rpm})$ with $0.05 \mathrm{M}$ citrate buffer $(\mathrm{pH}$ 4.8) by applying substrate:buffer (S:L 1:20) concentration for $1 \mathrm{~h}$ and filtered through Whatman No. 1 filter paper. The filtrates were centrifuged for $20 \mathrm{~min}$ at $4{ }^{\circ} \mathrm{C}$ to remove spores of the organism and the supernatant of crude enzyme extract was used for enzyme assay.

\section{Determination of enzyme activity}

Cellulase activity (FPA) was analyzed on filter paper, according to Ghose (1987). One unit of enzyme corresponds to the amount of enzyme necessary to form $1 \mu \mathrm{mol}$ of glucose per $\mathrm{ml}$ per minute. The reducing sugars were measured by the dinitrosalicylic acid (DNS) method according to Miller (1959).

Optimization of cellulase production

Factors such as amount of substrate, moisture content, concentration of inducer (lactose), incubation time and temperature that affect the growth of $T$. reesei NCIM 992 and the production of cellulase were determined (Lee et al. 2011). 
Enzymatic saccharification of sorghum straw

\section{Substrate}

Sorghum straw was collected from National Research Centre for Sorghum, Hyderabad, India. Dry stem pieces including leaf sheath were processed in a laboratory disintegrator to attain a particle size of $2-3 \mathrm{~mm}$ followed by washing with tap water until the washings were clear and then dried at $50{ }^{\circ} \mathrm{C}$ for overnight.

\section{Delignification}

For delignification, the substrate was suspended in $0.2 \mathrm{M}$ $\mathrm{NaOH}$ solution in the ratio of 1:10 and kept at room temperature for $18 \mathrm{~h}$. The contents were filtered and the residue was repeatedly washed with tap water until the $\mathrm{pH}$ of the residue became neutral. The residue was dried at $50{ }^{\circ} \mathrm{C}$, and subsequently used for acid/enzyme hydrolysis experiments.

\section{Acid hydrolysis}

The alkali pretreated substrate was subjected to acid hydrolysis with $3 \%$ sulfuric acid at $130{ }^{\circ} \mathrm{C}$ for $30 \mathrm{~min}$. The contents were filtered and the residue was used for second phase acid hydrolysis experiments.

For enzyme hydrolysis experiments the residue was repeatedly washed with tap water until the $\mathrm{pH}$ of the residue became neutral and dried at $50{ }^{\circ} \mathrm{C}$.

\section{Biphasic acid hydrolysis}

The 3\% acid-treated substrates were subjected to second phase acid hydrolysis with $5 \%$ sulfuric acid at $130{ }^{\circ} \mathrm{C}$ for $45 \mathrm{~min}$. The contents were filtered and the residue was repeatedly washed with tap water until the $\mathrm{pH}$ of the residue became neutral. The residue was dried at $50{ }^{\circ} \mathrm{C}$, and subsequently used for enzyme hydrolysis experiments.

\section{Enzymatic hydrolysis}

The enzymatic hydrolysis experiments were carried out in $100 \mathrm{ml}$ flasks with a working volume of $20 \mathrm{ml}$.

Untreated (control), alkali treated, alkali treated followed by single phase acid (3\%) treated and alkali treated followed by biphasic acid ( 3 and 5\%) treated sorghum straw were hydrolyzed with $25 \mathrm{FPU} / \mathrm{g}$ of crude cellulase in $0.05 \mathrm{M}$ citrate buffer ( $\mathrm{pH} 4.8$ ) at a substrate concentration of $5 \%(\mathrm{w} / \mathrm{v})$. The substrates were soaked in buffer for $2 \mathrm{~h}$ before adding the enzyme. Sodium-azide $(0.005 \%)$ was added to the reaction mixture to prevent microbial or fungal contamination.

The flasks were incubated at $50{ }^{\circ} \mathrm{C}$ on an orbital shaker at $150 \mathrm{rpm}$ for $60 \mathrm{~h}$. Sample aliquots of $1 \mathrm{ml}$ were taken at different times, centrifuged and the supernatants were analyzed for reducing sugars to determine the percentage of hydrolysis (\% saccharification).

The percentage of hydrolysis was calculated as follows

$$
\begin{aligned}
& \% \text { saccharification } \\
& =\frac{\text { reducing sugars in acid hydrolyzate }}{\text { total holocellulose in pretreated sample }} \times 100 \text {. }
\end{aligned}
$$

The delignified sorghum straw after 3\% acid hydrolysis when subjected to enzyme hydrolysis showed highest percentage of hydrolysis (42.5\%) and hence this substrate was selected for further optimization studies.

Optimization of enzymatic hydrolysis

Various parameters such as hydrolysis time, temperature, buffer, enzyme loading, substrate concentrations and addition of surfactant, etc., were studied to find out the best hydrolyzing conditions for sorghum straw using cellulase produced by $T$. reesei NCIM 992 on alkali treated rice straw. The optimum condition obtained from each experiment was used in the next optimization study unless otherwise stated.

\section{Optimization of hydrolysis time}

The enzymatic hydrolysis studies were carried out for a period of $60 \mathrm{~h}$ at $50{ }^{\circ} \mathrm{C}$, and we found that maximum hydrolysis $(42.5 \%)$ occurred at $36 \mathrm{~h}$ and remained constant thereafter. Further optimization studies were carried out for 36 h only.

\section{Optimization of enzyme loading}

The pretreated substrate was loaded with different concentrations of cellulase (10-30 FPU/g) to determine the optimum enzyme concentration required to hydrolyze the substrate. Hydrolysis was performed with $0.05 \mathrm{M}$ citrate buffer $(\mathrm{pH} 4.8)$ at $50{ }^{\circ} \mathrm{C}$ for $36 \mathrm{~h}$.

\section{Optimization of temperature}

Hydrolysis was performed at different temperatures (35, $40,45,50$ and $55^{\circ} \mathrm{C}$ ) to determine the optimum temperature for the hydrolysis with $25 \mathrm{FPU} / \mathrm{g}$ of crude cellulase in $0.05 \mathrm{M}$ citrate buffer ( $\mathrm{pH} 4.8$ ) for $36 \mathrm{~h}$. 


\section{Optimization of substrate concentration}

The substrate was suspended in fixed volume $(20 \mathrm{ml})$ of $0.05 \mathrm{M}$ citrate buffer ( $\mathrm{pH} 4.8$ ), with different weights of substrate $(0.2,0.4,0.6,0.8,1.0$ and $1.2 \mathrm{~g})$ and incubated for $36 \mathrm{~h}$ at $50{ }^{\circ} \mathrm{C}$.

\section{Optimization of surfactant and buffer}

Enzyme hydrolysis was performed with $1 \mathrm{~g}$ substrate in $20 \mathrm{ml} 0.05 \mathrm{M}$ acetate buffer ( $\mathrm{pH} 4.8$ ) at $50{ }^{\circ} \mathrm{C}$ for $36 \mathrm{~h}$ by the addition of Tween- 80 in the range of $0.05,0.1,0.15,0.2$ and $0.25 \mathrm{~g} / \mathrm{g}$. All experiments were performed in triplicates.

\section{Results and discussion}

\section{Enzyme production under SSF}

Rice straw is a by-product of rice production and a great bioresource. It is one of the abundant lignocellulosic waste materials in the world. Its annual production is about 731 million tons, which is distributed in Africa 20.9 million tons, Asia 667.6 million tons and Europe 3.9 million (Roberto et al. 2003).

According to Kim and Dale (2005) no rice straw must be left on the field to prevent erosion, so that rice straw could be made available for the utilization in bioethanol industry.

Pretreatment (steam, alkali or acid treatment) may reduce the indigenous microflora particularly required in SSF, where key enzymes must be pre-induced for a quick start of lignocellulose breakdown and fungal growth (Tengerdy and Szakacs 2003). Rita Rani et al. (2006) found that pretreatment of substrate increased the cellulase yields by $33 \%$.

Kang et al. (2004) reported $19.5 \mathrm{FPU} / \mathrm{g}$ on fourth day by SSF on rice straw using A. niger KK2. Our reports on enzyme activity are in close comparison with the findings of Deshpande et al. (2008) who reported 27.39 FPU/g with T. reesei (QM 9414 mutant) by SSF using water hyacinth, wheat bran, wood straw and their combinations as substrates.

Furthermore, Rita Rani et al. (2006) reported Fpase activity of $56.5 \mathrm{FPU} / \mathrm{gds}$ at $28{ }^{\circ} \mathrm{C}$ in SSF using pretreated sugarcane bagasse by $T$. reesei NRRL 11460 .

$\mathrm{Xu}$ et al. (2008) studied the effect of soluble disaccharides on cellulase activity and found significant enhancement from $11.7 \mathrm{U} / \mathrm{ml}$ of Fpase activity to $16.3 \mathrm{U} / \mathrm{ml}$ after fifth day when $1 \%$ lactose was incorporated in the medium. According to Lee et al. (2011), FPase activity of $3.4 \mathrm{U} / \mathrm{g}$ was obtained using local isolate Aspergillus niger USM AI 1 grown on sugarcane bagasse and palm kernel cake at 1:1 $(w / w)$ ratio under optimized SSF conditions.
We could obtain (Fig. 1) 30.7 FPU/gds of enzyme activity on fifth day of incubation with $80 \%$ moisture level and $1 \%$ lactose as inducer at $28{ }^{\circ} \mathrm{C}$ under SSF from rice straw using T. reesei NCIM 992. The Fpase activity may be further improved by optimizing various parameters and by improving the strain employed.

Delignification and acid hydrolysis

The holocellulose content of sorghum straw was found to contain $\quad(37.51 \pm 0.42 \%$ cellulose, $26.50 \pm 1.5 \%$ of hemicellulose, $19.0 \pm 0.27 \%$ of lignin and $10.02 \pm 1.05 \%$ of ash) on dry solid (DS) basis which is in accordance with Mehmood et al. (2009). The presence of lignin in cellulosic substrates hinders the saccharification of them into monomeric sugars. Therefore, to overcome the lignin barrier, lignocelluloses are usually pretreated initially with alkali to dissolve the lignin caused by the breakdown of ether linkages (Lee 1997). Efficient delignifying agent should remove a maximum of lignin and minimum of sugars (not more than 5\%) (Taherzadeh and Karimi 2007). Chemical alkali pretreatment at ambient temperatures is simple and time-saving and appears to have strong commercial potential (Kim and Holtzapple 2005). Sodium hydroxide is a typical alkali used in alkaline pretreatment (Varga et al. 2002).

Therefore, we have used sodium hydroxide $(\mathrm{NaOH})$ for delignification of sorghum straw for $18 \mathrm{~h}$ at $30 \pm 2{ }^{\circ} \mathrm{C}$ and we could achieve nearly $75 \%$ lignin loss with only $3.5 \%$ sugar loss.

Acid hydrolysis (3\% acid) of the delignified substrate resulted in $45 \%$ of hydrolysis and biphasic ( 3 and $5 \%$ ) acid hydrolysis of the substrate resulted in $65 \%$ (of total cellulose) hydrolysis.

Enzymatic saccharification of sorghum straw

When enzymatic hydrolysis was performed for untreated (control), alkali treated, alkali treated followed by single

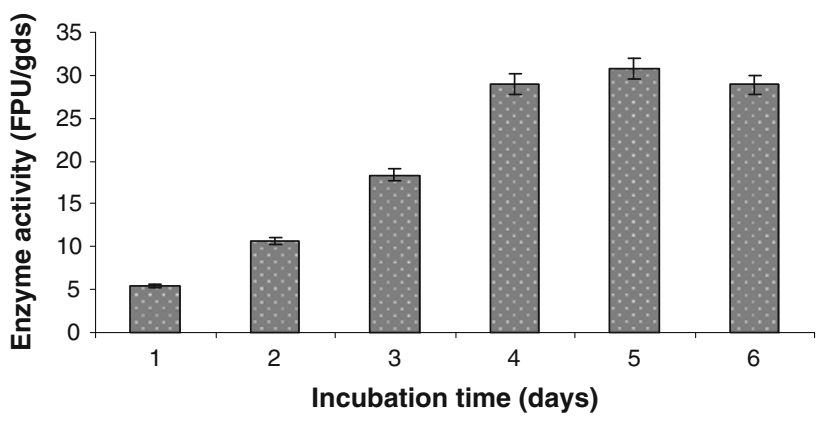

Fig. 1 Cellulase production by SSF using rice straw. Data shown are the mean of three experiments $(n=3)$. Error bars indicate standard error mean (SEM) 
phase acid (3\%) treated and alkali treated followed by biphasic acid (3 and 5\%) treated sorghum straw, we observed that alkali delignified followed by acid treated sorghum straw released highest amounts of sugars $(42.5 \%)$ when compared to other substrates (Fig. 2).

It has been established by Valchev et al. (2009) that the enzyme treatment on raw material as first stage treatment can be inefficient, probably because of impeded access of the enzyme molecules to the amorphous sections of the carbohydrate chains. Furthermore, they have identified considerable improvement in enzyme hydrolysis after acid hydrolysis of crushed maize stalks.

\section{Optimization of enzymatic saccharification}

For the improvement of enzymatic hydrolysis, it is necessary to optimize the critical process parameters such as optimum cellulase loading, temperature, saccharification time and substrate to liquid ratio. Enzymatic saccharification of the acid pretreated sorghum straw into glucose was optimized using the enzyme supernatant of $T$. reesei NCIM 992. These process parameters play a crucial role in enzymatic hydrolysis of lignocelluloses to get satisfactory yield of monomeric sugars. Optimization of time of enzymatic hydrolysis was done. Figure 2 shows that maximum sugars were released after $36 \mathrm{~h}$ showing the hydrolytic efficiency of $331.5 \pm 0.5 \mathrm{mg} / \mathrm{g}$ sugars with an efficiency of $42.5 \%$ at $50{ }^{\circ} \mathrm{C}$. A regular increase in released sugar amount was observed from 12 to $36 \mathrm{~h}$ and remained constant thereafter. An optimum enzyme concentration is required to hydrolyze the cellulose into glucose. The effect of enzyme loading on the enzymatic hydrolysis of pretreated sorghum straw has been studied and the results are presented in Fig. 3. The sugar yield increased sharply by increasing enzyme loading from 10 to $25 \mathrm{FPU} / \mathrm{g}$. Thereafter, there was no significant increase in sugar concentration. This shows that an optimum enzyme loading is required to hydrolyze the substrate into glucose. $42.5 \%$ of the enzymatic hydrolysis efficiency was achieved at an enzyme loading of $25 \mathrm{FPU} / \mathrm{g}$ with our enzyme for sorghum straw. Varga et al. (2002) found that the enzymatic conversion efficiency of corn stover pretreated with $\mathrm{NaOH}$ was between 70 and $80 \%$ with an enzyme loading of $42 \mathrm{FPU} / \mathrm{g}$.

The effect of temperature was studied to know the optimum temperature for maximum hydrolysis of cellulose into glucose. Figure 4 shows that maximum sugars released were $351 \mathrm{mg} / \mathrm{g}$ of sugars with an efficiency of $42.5 \%$ at $50{ }^{\circ} \mathrm{C}$ within $36 \mathrm{~h}$. The temperature $50{ }^{\circ} \mathrm{C}$ has been used as optimum for enzymatic hydrolysis of different lignocellulosics (Xu et al. 2006). We found similar observations in our studies.

The ratio of substrate to liquid is also a very important parameter in enzymatic hydrolysis of lignocellulosics. The effect of substrate concentration on enzyme hydrolysis was studied at a fixed ratio of cellulase loading (25 FPU/g) to different concentrations of substrate $(0.2,0.4,0.6,0.8,1.0$ and $1.2 \mathrm{~g}$ ) in a total reaction mixture of $20 \mathrm{ml}$. As shown in Fig. 5, the rate of conversion decreased when substrate taken was increased from 1 to $1.2 \mathrm{~g}$. Increase in substrate concentration limits the saccharification yields because of stirring difficulties, reduction of aqueous movable phase and end product inhibition (Szczodrak 1999).

A maximum of $351 \mathrm{mg} / \mathrm{g}$ of sugars with an efficiency of $42.5 \%$ at $50{ }^{\circ} \mathrm{C}$ after $36 \mathrm{~h}$ was obtained. Increasing the substrate level further showed a downfall in sugar amount which clearly indicates that optimum concentration of substrate to buffer is required for maximum hydrolysis of cellulose. The reason could be due to the fact that the rate and extent of biomass hydrolysis are inextricably linked to biomass structural characteristics (Zhu 2005). Optimization of surfactant concentration and effect of buffer on enzyme hydrolysis were also studied when $0.05 \mathrm{mM}$ acetate buffer ( $\mathrm{pH} 4.8$ ) was used for the hydrolysis of sorghum straw with $0.2 \mathrm{~g} / \mathrm{g}$ of Tween-80. There was an increase in hydrolysis from 45 to $70 \%$ (based on cellulosic fraction) with a maximum of $546.00 \pm 0.55 \mathrm{mg} / \mathrm{g}$ of sugars (Fig. 6).

Recent studies show that enzyme saccharification yields can be enhanced using surfactants (Tween-20, Tween-80 or PEG) or BSA (bovine serum albumin) (Tabka et al. 2006). It has also been reported that surfactants could increase the
Fig. 2 Hydrolysis of differently pretreated sorghum straw with cellulase of $T$. reesei. Data shown are the mean of three experiments $(n=3)$. Error bars indicate standard error mean (SEM)

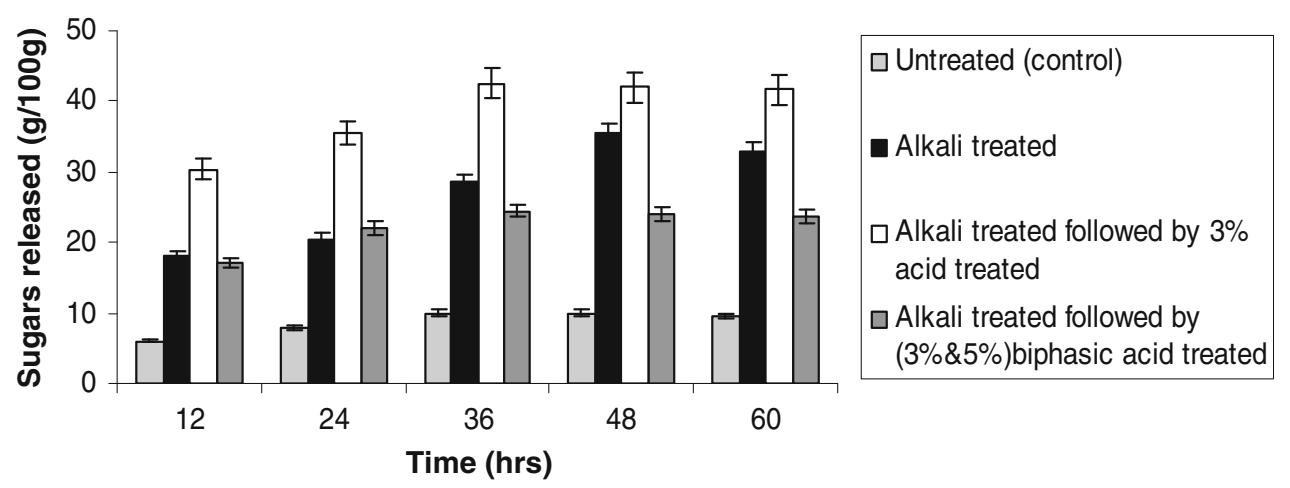




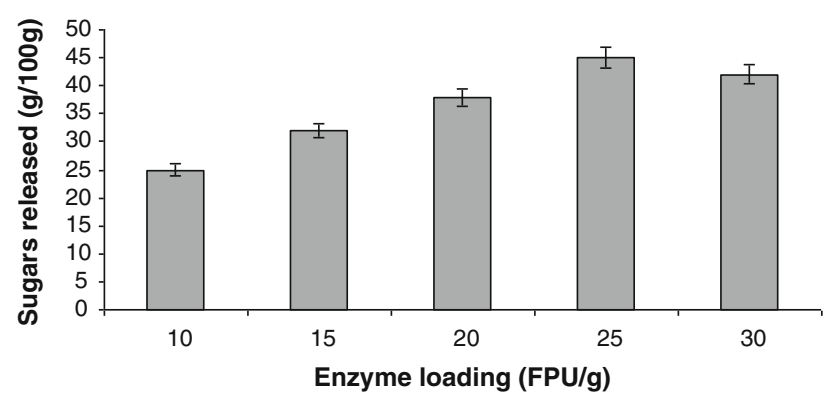

Fig. 3 Effect of different enzyme loadings on hydrolysis of sorghum straw. Data shown are the mean of three experiments $(n=3)$. Error bars indicate standard error mean (SEM)

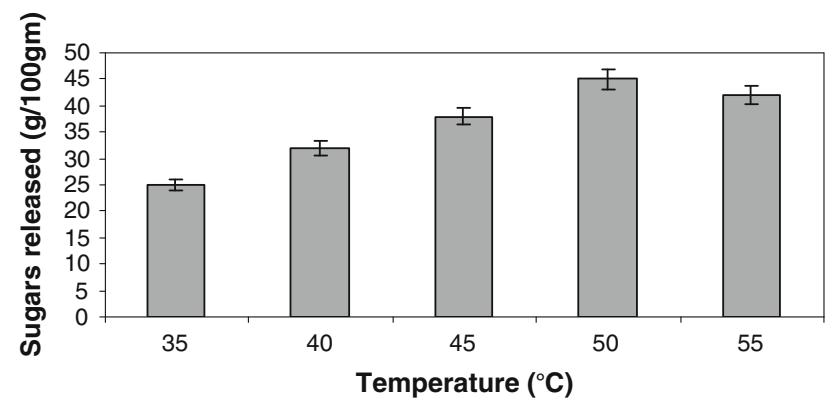

Fig. 4 Effect of different temperatures on hydrolysis of sorghum straw. Data shown are the mean of three experiments $(n=3)$. Error bars indicate standard error mean (SEM)

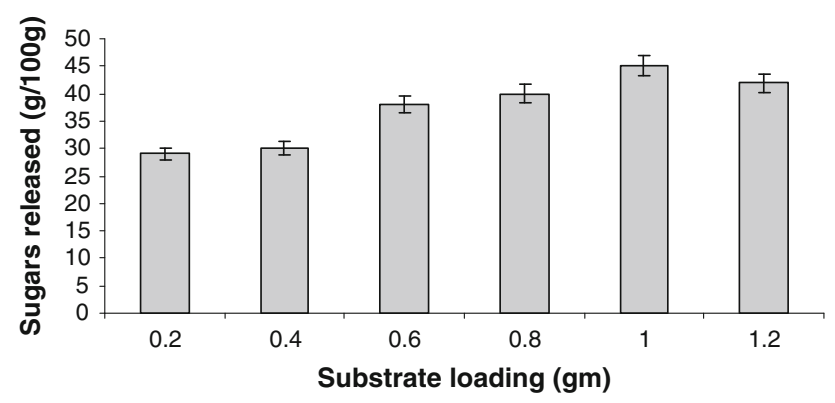

Fig. 5 Effect of different substrate loadings on hydrolysis of sorghum straw. Data shown are the mean of three experiments $(n=3)$. Error bars indicate standard error mean (SEM)

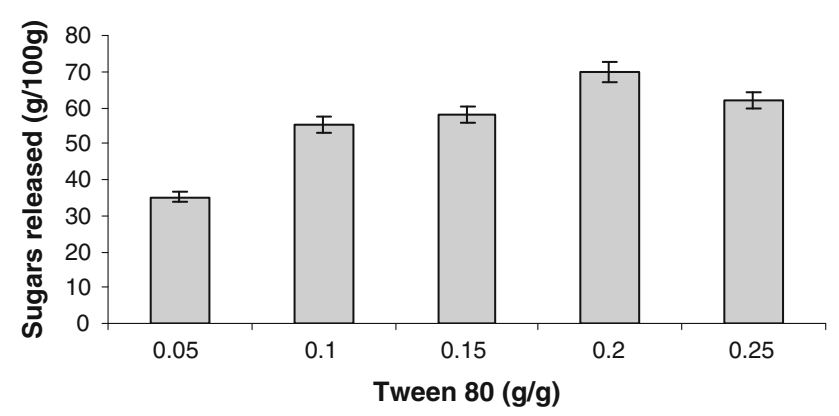

Fig. 6 Effect of different concentrations of surfactant on hydrolysis of sorghum straw. Data shown are the mean of three experiments $(n=3)$. Error bars indicate standard error mean (SEM) stability of cellulase (Kaar and Holtzapple 1998). Surfactant as an enzyme stabilizer contributes to better performance of cellulose hydrolysis. Yao et al. (2007) found 20\% increase in the enzymatic saccharification of rice straw by the addition of surfactant.

Cara et al. (2008) reported the maximum hemicelluloses recovery $(83 \%)$ of olive tree biomass to be obtained at $170{ }^{\circ} \mathrm{C}$ and $1 \%$ sulfuric acid concentration, but the enzyme accessibility of the corresponding pretreated solid was not very high. Saha et al. (2005) found a maximum yield of fermentable sugars $(485 \mathrm{mg} / \mathrm{g}, 64 \%$ of total carbohydrates) from acidic pretreated wheat straw $[7.83 \%$ (w/v), DS, acid dose of $0.75 \%(v / v)]$. Only $47 \%$ cellulose (203 mg/gds) was converted to glucose. Recently, Kim et al. (2008) reported the enzymatic digestibility of the ammonia pretreated barley husk to be $83 \%$ for glucan and $63 \%$ for xylan with $15 \mathrm{FPU} / \mathrm{g}$ glucan enzymes loading. Sunflower hulls hydrolyzed with $T$. reesei Rut C30 cellulase (25 FPU/g of substrate) showed 59.8\% saccharification after pretreatment with sodium hydroxide $0.5 \%$ (w/v) (Sharma et al. 2004). Verônica et al. (2010) obtained $149.6 \mathrm{~g} / \mathrm{l}$ of glucose from pretreated sugarcane bagasse when $25 \mathrm{FPU} / \mathrm{g}$ of substrate was loaded. We could obtain a maximum of $70 \%(546 \pm 0.5 \mathrm{mg} / \mathrm{g})$ hydrolysis of acid treated sorghum straw with crude cellulase of $T$. reesei NCIM 992.

\section{Conclusion}

The present study was aimed at enzymatic hydrolysis of sorghum straw, a lignocellulosic substrate using crude cellulase produced under SSF. Under the optimized SSF conditions, about $30.7 \mathrm{U} / \mathrm{g}$ of FPase activity was obtained from T. reesei NCIM 992 using $\mathrm{KOH}$ pretreated rice straw. When acid treated sorghum straw was subjected to enzymatic hydrolysis with cellulase of $T$. reesei NCIM 992, $70 \%(546 \pm 0.5 \mathrm{mg} / \mathrm{g})$ of sugars were recovered after optimization of enzyme loading, temperature, time and substrate to liquid ratio, addition of surfactant and buffer. In comparison with chemical hydrolysis, enzymatic hydrolysis does not require large volumes of chemicals and usually conducted at mild conditions, hence does not have a corrosion problem. Furthermore, chemical hydrolyzates need to be detoxified before carrying out fermentation. Therefore, enzymatic saccharification for the production of bioethanol from lignocellulosic substrates is an efficient process that has the potential to become most promising method for hydrolysis.

Acknowledgments The authors are thankful to the Department of Science and Technology, New Delhi, India, for the financial assistance. 
Open Access This article is distributed under the terms of the Creative Commons Attribution License which permits any use, distribution and reproduction in any medium, provided the original author(s) and source are credited.

\section{References}

Acharya PB, Acharya DK, Modi AH (2008) Optimization for cellulase production by Aspergillus niger using saw dust as substrate. Afr J Biotechnol 7(22):4147-4152

Cantwell BA, Sharp PM, Gormley E, Mcconnell DJ (1988) Molecular cloning of Bacillus $\beta$-glucosidase. In: Aubert JP, Beguin P, Millet $\mathbf{J}$ (eds) Biochemistry and genetics of cellulose degradation. Academic press, San Diego, pp 181-201

Cara C, Ruiz E, Oliva JM, Saez F, Castro E (2008) Conversion of olive tree biomass into fermentable sugars by dilute acid pretreatment and enzymatic saccharification. Bioresour Technol 99:1869-1876

Cheng KK, Cai BY, Zhang JA, Ling HZ, Zhou YJ, Ge JP, Xu JM (2008) Sugarcane bagasse hemicellulose hydrolysate for ethanol production by acid recovery process. Biochem Eng J 38:105-109

Cherry JR, Fidantsef AL (2003) Directed evolution of industrial enzymes: an update. Curr Opin Biotechnol 14:438-443

Deshpande SK, Bhogmange MG, Chakrabarti T, Shastri PN (2008) Production of cellulose and xylanase by Trichoderma reesei $(\mathrm{Q}$ 9414 mutant), Aspergillus niger and mixed culture by solid state fermentation (SSF) of water hyacinth (Eichornia crassipes). Indian J Chem Technol 15:449-456

Duff SJB, Murray WD (1996) Bioconversion of forest products industry waste cellulosics to fuel ethanol: a review. Bioresour Technol 55:1-33

Galbe M, Zacchi G (2002) A review of the production of ethanol from softwood. Appl Microbiol Biotechnol 59:618-628

Ghose TK (1987) Measurement of cellulase activities. Pure Appl Chem 59:257-268

Himmel ME, Ruth MF, Wyman CE (1999) Cellulase for commodity products from cellulosic biomass. Curr Opin Biotechnol 10:358-364

Kaar WE, Holtzapple M (1998) Benefits from Tween during enzymatic hydrolysis of corn stover. Biotechnol Bioeng 59:419-427

Kang SW, Park YS, Lee JS, Hong SI, Kim SW (2004) Production of cellulose and hemicellulases by Aspergillus niger KK2 from lignocellulosic biomass. Bioresour Technol 91:153-156

Karimi K, Emtiazi G, Taherzadeh MJ (2006) Production of ethanol and mycelial biomass from rice straw hemicellulose hydrolyzate by Mucor indicus. Process Biochem 41(3):653-658

Kim S, Dale BE (2005) Global potential bioethanol production from wasted crops and crop residues. Biomass Bioenerg 29:361-375

Kim S, Holtzapple MT (2005) Lime pretreatment and enzymatic hydrolysis of corn stover. Bioresour Technol 96:1994-2006

Kim HT, Kim JS, Sunwoo C, Lee YY (2008) Pre-treatment of corn stover by aqueous ammonia. Bioresour Technol 90:39-47

Krishna C, Chandrasekaran M (1996) Banana waste as substrate for $\alpha$-amylase production by Bacillus subtilis BTK (106) solid state fermentation. Appl Microbiol Biotechnol 46:106-111

Kumar R, Singh S, Singh OV (2008) Bioconversion of lignocellulosic biomass: biochemical and molecular perspectives. J Ind Microbiol Biotechnol 35:377-391

Lee J (1997) Biological conversion of lignocellulosic biomass to ethanol. J Biotechnol 56:1-24

Lee YY, Iyer P, Torget RW (1999) Dilute-acid hydrolysis of lignocellulosic biomass. Adv Biochem Eng Biotechnol 65:94-115
Lee CK, Darah I, Ibrahim CO (2011) Production and optimization of cellulase enzyme using Aspergillus niger USM AI 1 and comparison with Trichoderma reesei via solid state fermentation system. Biotechnol Res Int 2011(658493):6. doi: $10.4061 / 2011 / 658493$

Lynd LR, Weimer PJ, Van Zyl WH, Pretorius IS (2002) Microbial cellulose utilization: fundamentals and biotechnology. Microbiol Mol Biol Rev 66:506-577

Mandels M, Andreotti RE (1978) Problems and challenges in the cellulose to cellulase fermentation. Process Biochem 13:6-13

Mansfield DS, Mooney C, Saddler JN (1999) Substrates and enzyme characteristics limit cellulose hydrolysis. Biotechnol Progr $15: 804-816$

Mehmood S, Gulfraz M, Rana NF, Ahmad A, Ahring BK, Minhas N, Malik MF (2009) Ethanol production from Sorghum bicolor using both separate and simultaneous saccharification and fermentation in batch and fed batch systems. Afr J Biotechnol 8(12):2857-2865

Miller GL (1959) Use of dinitrosalicylic acid reagent for determination of reducing sugar. Anal Chem 31:426-428

Mussatto SI, Roberto IC (2004) Alternatives for detoxification of diluted-acid lignocellulosic hydrolysates for use in fermentative process: a review. Bioresour Technol 93:1-10

Nigam P, Singh D (1996) Processing of agricultural wastes in solid state fermentation for cellulolytic enzyme production. J Sci Ind Res 55:453-463

Oguntimein G, Vlach D, Moo-Young M (1992) Production of cellulolytic enzymes by Neurospora sitophila grown on cellulosic materials. Bioresour Technol 39:277-283

Pandey A (2003) Solid-state fermentation. Biochem Eng J 13:81-84

Philippids GP, Smith TK (1995) Limiting factors in the simultaneous saccharification and fermentation process for conversion of cellulosic biomass to fuel ethanol. Appl Biochem Biotechnol 51(52):117-124

Reczey K, Szengyel Z, Eklund R, Zacchi G (1996) Cellulase production by Trichoderma reesei. Bioresour Technol 57:25-30

Reddy BVS, Sanjana Reddy P (2003) Sweet sorghum: characteristics and potential. Int Sorghum Millets News Lett 44:26-28

Rita Rani S, Sukumaran RK, Pillai A, Prema P, Szakacs G, Pandey A (2006) Solid state fermentation of lignocellulosic substrates for cellulase production by Trichoderma reese NRRL 11460. Indian J Biotechnol 5:332-336

Roberto IC, Mussatto SI, Rodrigues RCLB (2003) Dilute-acid hydrolysis for optimization of xylose recovery from rice straw in a semi-pilot reactor. Ind Crops Prod 7:171-176. doi: 10.1016/S0926-6690(02)00095-X

Rodriguez Couto S, Sanroman AM (2005) Application of solid state fermentation to lignolytic enzyme production. Biochem Eng $\mathrm{J}$ 22:211-219

Saha BC, Iten LB, Cotta MA, Wu YU (2005) Dilute acid pretreatment, enzymatic saccharification and fermentation of wheat straw to ethanol. Process Biochem 40:3693-3700

Sharma SK, Kalra KL, Kocher GS (2004) Fermentation of enzymatic hydrolysate of sun flower hulls for ethanol production and its scale-up. Biomass Bioenerg 27:392-399

Smits JP, Rinzema A, Tramper J, Van Sonsbeek HM, Knol W (1996) Solid-state fermentation of wheat bran by Trichoderma reesei QM9414: substrate composition changes, $\mathrm{C}$ balance, enzyme production, growth and kinetics. Appl Microbiol Biotechnol 46(5-6):489-496

Soccol CR, Vandenberghe LPS (2003) Current developments in solid state fermentation. Biochem Eng J 13:205-218

Spano L (1978) Enzymatic hydrolysis of cellulose to fermentable sugar for the production of ethanol. In: Shuster WW (ed) Proceedings of annual symposium on fuels from biomass. Wiley, New York, pp 671-684 
Sun Y, Cheng J (2002) Hydrolysis of lignocellulosic materials for ethanol production: a review. Bioresour Technol 83:1-11

Szczodrak J, Ilezuk A, Rogalski J, Leonowicz A (1999) Intensification of oak saw dust enzymatic hydrolysis by chemical or hydrothermal pretreatment. Process Biochem 35:33-41

Tabka MG, Herpoel-Gimbert I, Monod F, Asther M, Sigollot JC (2006) Enzymatic saccharification of wheat straw for bioethanol production by a combined cellulose xylanase and feruloyl esterase treatment. Enzyme Microbial Technol 39:897-902

Taherzadeh MJ, Karimi K (2007) Acid based hydrolysis process for bioethanol production from lignocellulosic materials: a review. Bioresources 2:472-499

Tengerdy RP, Szakacs G (2003) Bioconversion of lignocellulose in solid state fermentation. Biochem Eng J 13:169-179

Valchev I, Nenkova S, Petya Tsekova P, Lasheva V (2009) Use of enzymes in hydrolysis of maize stalks. Bioresources 4(1):285-291

Varga E, Szengyel Z, Reczey K (2002) Chemical pretreatment of corn stover for enhancing enzymatic hydrolysis. Appl Biochem Biotechnol 98:73-87

Verônica F, Mariana de Oliveira F, Sabrina da Silva M, Pereira N Jr (2010) Simultaneous saccharification and fermentation process of different cellulosic substrates using a recombinant
Saccharomyces cerevisiae harbouring the $\beta$-glucosidase gene. Electron J Biotechnol 13(2):0717-3458

Von Sivers M, Zacchi G (1995) A techno-economical comparison of three processes for the production of ethanol. Bioresour Technol 51:43-52

Wen Z, Liao W, Sh Chen (2005) Production of cellulase by Trichoderma reesei from dairy manure. Bioresour Technol 96:491-499

Wilson DB (2009) Evidence for a novel mechanism of microbial cellulose degradation. Cellulose 16:723-727

Xu F, Sun JX, Liu CF, Sun RC (2006) Comparative study of alkaliand acidic organic solvent-soluble hemicellulosic polysaccharides from sugarcane bagasse. Carbohydr Res 341:253-261

Xu F, Yano S, Hiroyuki I, Sawayama S (2008) Lactose enhances cellulase production by the filamentous fungus Acremonium cellulolyticus. J Biosci Bioeng 106(2):115-120

Yao R, Qi B, Deng S, Liu N, Peng S, Cui Q (2007) Use of surfactant in enzymatic hydrolysis of rice straw and lactic acid production from rice straw by simultaneous saccharification and fermentation. Bioresources 2(3):38-398

Zhu L (2005) Fundamental study of structural features affecting enzymatic hydrolysis of lignocellulosic biomass, dissertation. A\&M University, Texas 